\title{
PSYCHE
}

\begin{tabular}{lll}
\hline Vol. LI & Mar.-June, 1944 & Nos. 1-2 \\
\hline
\end{tabular}

\section{HOW ODYNERUS SUSPENDS HER EGG}

\author{
By Carl G. Hartman \\ Department of Zoölogy and Physiology \\ University of Illinois, Urbana, Illinois
}

So far as the writer is aware it was he and his sons, Philip and Paul, amateur entomologists, who first witnessed a Eumenid wasp expel her egg and hang it from the ceiling of her nest - or rather suspend it and then expel the egg, for, as a matter of fact, the thread is made first. Dame Fortune was with us further in that the very first time we witnessed the act we had the movie camera set up, loaded with Kodachrome, and so secured a motion picture of oviposition.

For some forty years, on numerous occasions, I have amused myself and bored tolerant friends by attracting certain solitary bees and wasps ("tube fillers") to my window-sill by setting out tubes of various diameters suitable for their occupancy. Trypoxylon and Odynerus were sure to be there, also small bees as well as the larger Megachile, the leaf cutter. The last mentioned proved especially popular with the amateur naturalist. The method most often employed was that well described and figured by Savin (Natural History, 1922). This method consists essentially of screwing together two smooth-faced boards and boring holes of various diameters down the surface of junction. By removing the screws the work of insects could readily be laid bare. Bamboo tubes and even rubber tubing were also set out, but the latter does not favor the survival of the wasp grubs. In vacation time of I94I, however, at Bethlehem, Connecticut, all energies were devoted to watching and photographing the insects as they worked in glass tubes. No better means can be imagined for prying into the insects' domestic activities than by inducing them to live in glass houses! In this the insects proved most coöperative. 
It is the object of the present paper to describe the egg-laying of Odynerus (Rygchium) rugosus (Sauss) = foraminatus (Sauss) as observed and photographed by the glass-tube method.

Bamboo tubes which served as sheaths for the glass tubes so as to afford the requisite darkness of the interior, were tacked on a tree-trunk or the side of the house or other comfortable shady place, and developments awaited. Light for instantaneous photography was secured by reflecting sunlight on the tube by means of a mirror.

The egg is always laid before the prey is captured and the cell stored. Trypoxylon and many others reverse this sequence. The signal for the egg-laying ceremony consists in the wasp's turning around and backing into the tube. Egg laying is the only act for which this orientation is necessary.

After entering the tube the more or less excitable female comes gradually to rest supinely on her wings, with tip of abdomen directed upward close to the mud partition. The rapid breathing movements (air temperature $90^{\circ} \mathrm{F}$ !) are soon accompanied by another type of movement, a comparatively slow, rhythmic contraction of the abdomen, in which the abdominal segments seem alternately to telescope and evert as the tip of the abdomen is retracted and extended. In the words of the observant young assistants: "She's pumpin' an egg." With each extension of the abdomen the tip comes in contact with the ceiling. Presently a drop of whitish secretion appears and is touched to the ceiling. There it sticks; and as the abdomen is withdrawn a thread is drawn out and instantly hardens, remaining flexible and tough, for subsequent movements of the abdomen do no injury to it.

The abdominal movements continue uninterruptedly until gradually the egg begins to slide out. The motion picture shows the egg free for about one-third of its length when a sudden jump in the film occurs to the point where the egg is two-thirds emerged, the interval marking the time that the camera was being rewound.

As soon as the egg is free, it is seen to dangle by its thread like a tiny pendulum.

\section{Function of the Thread}

On the adaptive significance of the suspensory thread of the Eumenid egg or its possible phylogenic history, the writer has no contribution to make. Several observations, however, may be cited confirmatory of Ch. Ferton's contention (Collected Works, 
I923) that Fabre laid too much stress on the correlation of the well-known liveliness of Eumenid's caterpillars and the alleged delicacy of the Eumenid egg.

It is a matter of common observation that the Eumenid prey is seldom stung to death. On opening a nest of Eumenes or Odynerus practically all of the caterpillars respond to stimulation and many move spontaneously. It is not at all a rare occurrence that a caterpillar begins to crawl as soon as set free. One of the scenes in our motion pictures of Eumenes is that of a merry scramble of four or five surviving caterpillars with two large wasp grubs holding on - for this case concerned an exceptional nest in which two eggs had been laid.

Fabre considered the egg much too delicate to stand the jostling of such vivacious prey entombed alive; he states that he was never able to rear grubs from eggs that were disturbed or removed from their original sites. But not so Ferton, who seldom failed under similar circumstances. Indeed, he once dropped an egg with the lively canker worms into a bottle, carried the specimens some miles on horseback, yet reared a wasp from the egg. We have also reared wasps from eggs that had been carried about in the jug nests of Eumenes or in bamboo tubes stored by Odynerus, although these were not handled with any special reference to the force of gravity.

Ferton points out, furthermore, that the cells are usually so tightly packed with caterpillars that the egg must needs be pressed against the wall and not able to dangle freely at all. This can readily be corroborated by opening almost any fully stored cell. If one split a bamboo tube full of caterpillars, it will be seen that the masses of worms literally swell up as the retaining wall is removed.

To these points we are able to add our direct observation on what happens to the egg as viewed through the wall of the glass tube while the insect is at work.

After the egg has been suspended in the depth of the cell, foraging begins. As the caterpillars are brought in they are stuffed with might and main into a closely fitting firm mass at the bottom of the cell. This happens also in smooth-walled glass tubes in which the worker finds only a precarious footing. The egg is always pushed around and often squeezed against the glass or between caterpillars, which are thus thoroughly immobilized by virtue of mutual pressure.

Ferton is of the opinion that the chief value of the suspensory 
thread for racial survival lies in the avoidance of contact by the egg with the wet wall of the cell. All predacious wasps seem particular as to the site of attachment of the egg, usually choosing the upper surface of the prey; or, if the egg is laid on the ground, as in the case of certain fly-catchers that feed the prey from day to day, a pebble is chosen to receive the egg. Of interest in this connection is the "transitional" habit of Rhaphiglossa zethoides, a solitary Vespid which attaches its egg, not by a thread, but by an elongated end in such a way that the egg projects away from the wall at an angle of about $45^{\circ}$. This wasp is of further phylogenetic interest in the use of both wood fiber, after the manner of the social wasps, and mud, which solitary Sphecina as well as Vespina usually employ.

Summary. The act of oviposition of Odynerus rugosus is here described and the probable function of the suspensory thread of the Eumenid egg is discussed. 

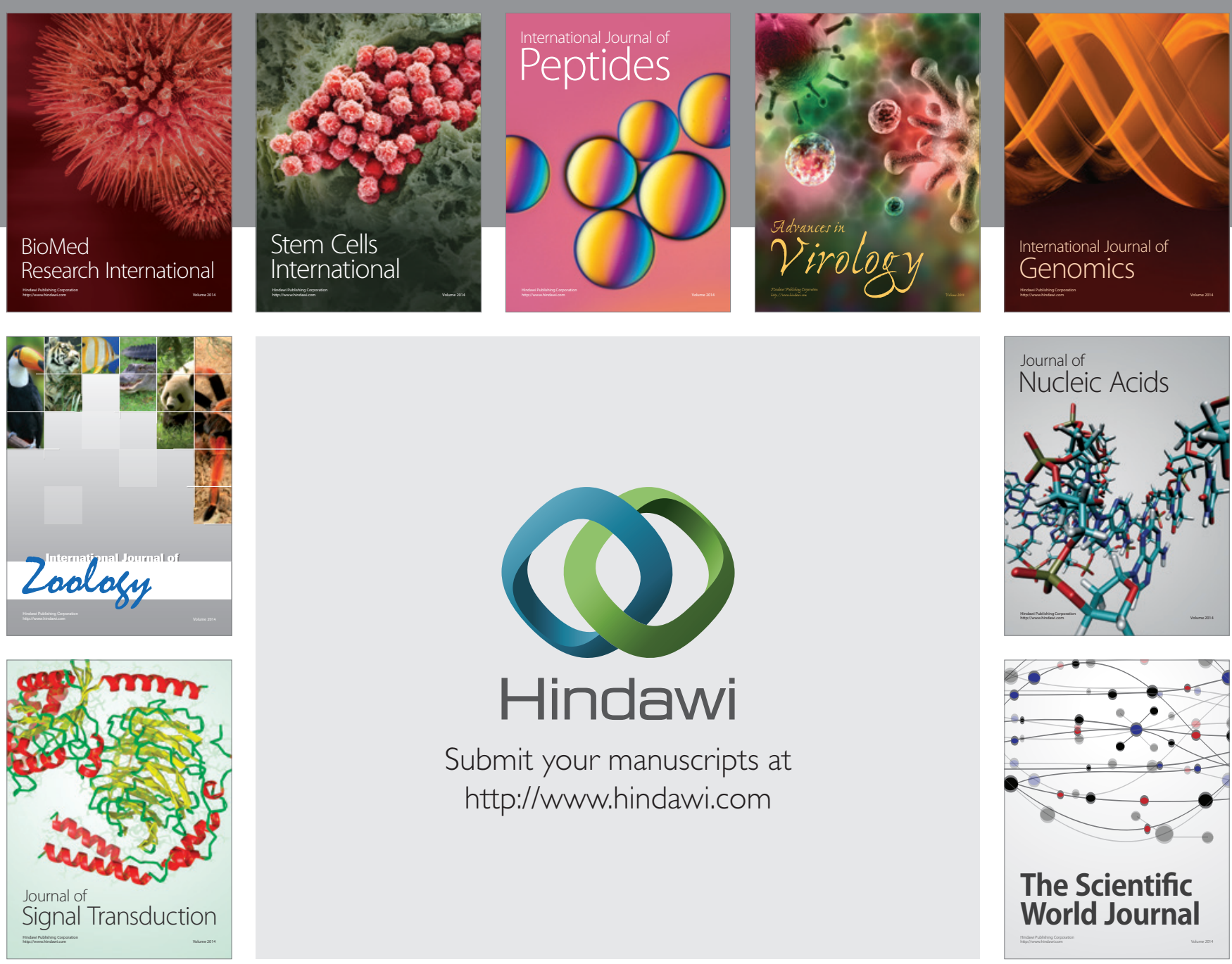

Submit your manuscripts at

http://www.hindawi.com
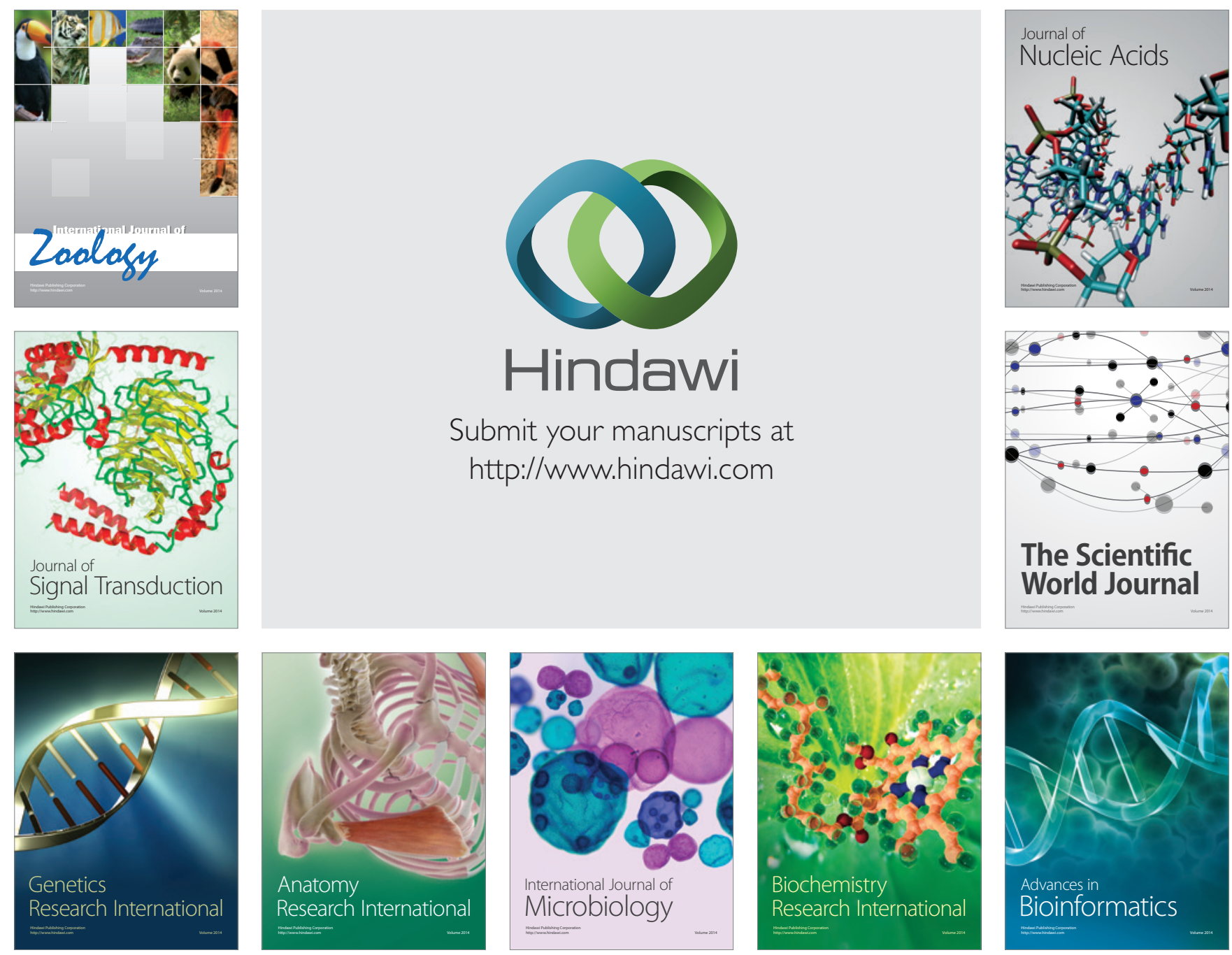

The Scientific World Journal
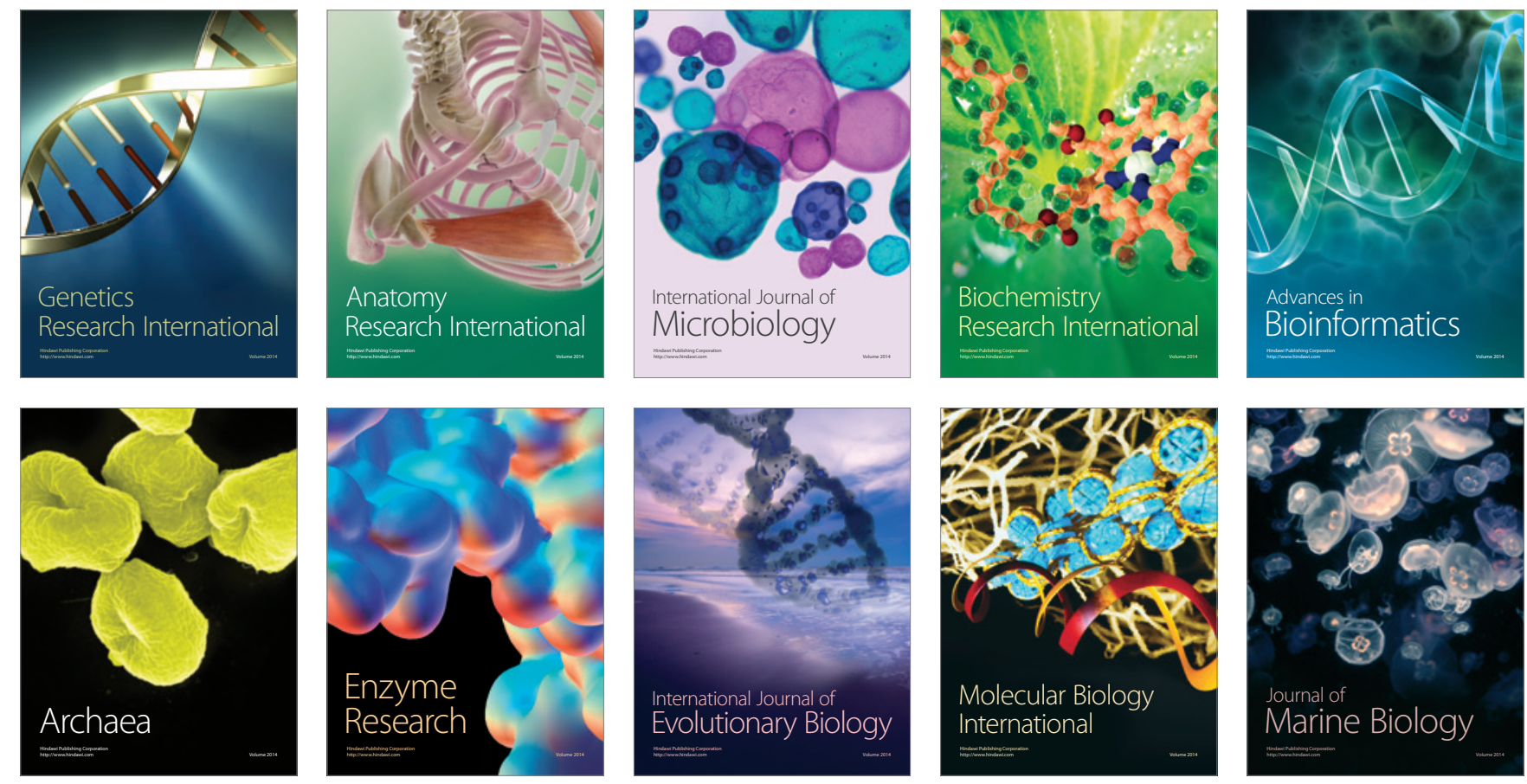